University of Nebraska - Lincoln

DigitalCommons@University of Nebraska - Lincoln

1982

\title{
Permeability, Underpressures, and Convection in the Oceanic Crust Near the Costa Rica Rift, Eastern Equatorial Pacific
}

Roger N. Anderson

Columbia University, anderson@Ideo.columbia.edu

Mark D. Zoback

U.S. Geological Survey, zoback@stanford.edu

Follow this and additional works at: https://digitalcommons.unl.edu/usgsstaffpub

Part of the Earth Sciences Commons

Anderson, Roger N. and Zoback, Mark D., "Permeability, Underpressures, and Convection in the Oceanic Crust Near the Costa Rica Rift, Eastern Equatorial Pacific" (1982). USGS Staff -- Published Research. 456. https://digitalcommons.unl.edu/usgsstaffpub/456

This Article is brought to you for free and open access by the US Geological Survey at DigitalCommons@University of Nebraska - Lincoln. It has been accepted for inclusion in USGS Staff -- Published Research by an authorized administrator of DigitalCommons@University of Nebraska - Lincoln. 


\title{
Permeability, Underpressures, and Convection in the Oceanic Crust Near the Costa Rica Rift, Eastern Equatorial Pacific
}

\author{
Roger N. ANDERSON \\ Lamont-Doherty Geological Observatory and Department of Geological Sciences, Columbia University \\ Palisades, New York 10964
}

MARK D. ZoBACK

U.S. Geological Survey, Menlo Park, California 94025

\begin{abstract}
In situ permeability and pore pressures were measured $200 \mathrm{~m}$ deep beneath the top of the oceanic crust at DSDP site 504B. These measurements have relevance for the transition from convective to conductive heat flow on the south flank of the Costa Rica Rift. Conventional 'slug' and constant rate injection tests were made below a hydraulic packer set at various depths in the hole. The packer was first set in a massive flow unit $37 \mathrm{~m}$ below the sediment-basement interface. The bulk permeability of the $172.5 \mathrm{~m}$ of pillow basalts and basaltic flows below the packer was found to be about $\mathbf{4 0}$ millidarcys $\left(4 \times 10^{-10} \mathrm{~cm}^{2}\right)$. Measurements over 3- and $15-\mathrm{m}$ intervals at the bottom of the hole in an altered pillow zone indicated a bulk permeability of 2-4 millidarcys. These values are thought to be accurate to $\pm 30 \%$. Formation pore pressures were found to be approximately 8 bars $(\sim 2 \%)$ below hydrostatic. Interpretation of the data with respect to simple numerical convection models suggests that the transition from convective to conductive heat flow is controlled by the cessation of convective heat transport through the sedimentary layer rather than the cessation of convection in the sediment. Furthermore, the agreement between observed and modeled underpressures implies that hole 504B penetrated an active ocean crustal convection system. The thick sedimentary layer, layers of basal chert, and massive flow basalts above the layer 2A pillow flows apparently form an impermeable lid, effectively isolating the convection system from the ocean.
\end{abstract}

\section{The Problem}

Convection of sea water through the oceanic crust at midocean ridge axes is now a well-established physical observation. Hydrothermal plumes exhaling metal-saturated 'black smokers' at temperatures of $350^{\circ} \mathrm{C}$ and velocities of meters per second have been captured dramatically on film and video tape [Spiess et al., 1980]. Mantle outgassing anomalies [Clark et al., 1970; Lupton and Craig, 1980] and large fluxes of major, minor, and trace elements out of the ridge axis [Corliss et al., 1979; Edmond et al., 1979] also indicate intense hydrothermal activity. Such activity was first observed at the Galapagos Spreading Center, where a remarkable suite of animal life, including giant tube worms and large clams, were found to be subsisting on sulfur-eating bacteria near the hot springs [Corliss et al., 1979].

Midocean ridge-axis geothermal systems appear to evolve into colder water convection systems which are active to great distances on the flanks of the ridges. The largest set of observations arguing for this continued convective activity is geothermal measurements. Regionally, much of the predicted heat flux of the cooling lithosphere is found to be missing when observations of conductive heat loss at the sea floor are made [Anderson and Hobart, 1976; Sclater et al., 1976; Anderson et al., 1977]. Heat might still be missing when the component of heat loss due to convection of pore water through the surficial sediments is added to this term. Aside from the fundamental measurement of the permeability of the oceanic crust, the basic question we wished to address was whether the heat flow transition is due to the cessation of convective heat transfer through the sedimentary layer

Copyright $\mathbb{C} 1982$ by the American Geophysical Union.

Paper number 1B1803.

0148-0227/82/001B-1803\$05.00 (with the basaltic layer continuing to have high permeability) and/or to a cessation of convection in the basement (perhaps due to the progressive alteration and remineralization of the older crust) resulting in low permeability.

\section{THE Working Model}

Near the Galapagos Spreading Center, nonlinear thermal gradients, widespread pore-water chemical anomalies, and metallogenesis show that a convection system penetrates the sedimentary layer and therefore carries significant heat directly from the oceanic crust to the oceans [Corliss et al., 1979; Green et al., 1981; Williams et al., 1974]. However, as the sea floor spreads away from the ridge axis, the convective component of heat transfer is gradually replaced by a totally conductive thermal regime at the sea floor.

To develop insight into how the heat flow transition is dependent upon measurable physical properties, Anderson and Skilbeck [1981] modelled the oceanic crust and overlying sediment as a two-layer porous medium. Cellular convection was driven with a horizontally varying, sinusoidal pressure field of arbitrary amplitude. Parameterization of the sealing mechanism suggests that significant transport of heat by convection stops across the sea floor if the permeability of the sediment, $k_{s}$, divided by the sediment thickness $h$ is much less than the wave number $a$ (defined as $2 \pi /$ wavelength) of each cell times the crustal permeability $k_{b}$. Gartling and Anderson [1981] constructed a finite element model of this two-layer porous media example and further quantified the relationship to show that whenever

$$
\frac{k_{s}}{a h k_{b}}<0.1
$$

convection becomes an insignificant carrier of heat across the top of the sedimentary layer. Our working model is that 
the transition from convective to conductive heat flow is due to the cessation of convection through the sedimentary layer. This hypothesis can be tested by studying variations in the physical parameters of (1). Thus, if $k_{s}$ is sufficiently small, or $a h k_{b}$ is sufficiently large, convective heat transport through the sediments essentially stops. It should be emphasized that when (1) is satisfied, convection may continue to be rigorous in the basement layer beneath the sediment: the sediment would then form a hydraulic lid. However, if the basaltic permeability decreased to too small a value, basement convection would stop independently of the interrelation between sedimentary and basaltic properties defined in (1), and a transition from convective to conductive heat flow at the sea floor would also result.

In order to test these concepts, it is necessary to know sediment and crustal permeabilities, sediment thickness, and the wavelength of the heat flow variation along the sea floor. While measurements of wavelength [e.g., Anderson et al., 1979; Davis et al., 1980] and sediment thickness are relatively easy, and sediment permeability data have been rapidly accumulating in the last few years [e.g., Bryant et al., 1975; Abbott et al., 1981; Crowe and Silva, 1981], no direct observation of the permeability of the oceanic crust had been made prior to this study. Indirect predictions of the permeability of oceanic crustal rocks have varied enormously. Crack width to spacing ratios, formation electrical resistivity, and porosity data have yielded values higher than most natural geological formations on land: $10^{2}-10^{4}$ darcies $\left(10^{-4}\right.$ $10^{-6} \mathrm{~cm}^{2}$ ) [Johnson, 1980a; Salisbury et al., 1979]. Geothermal convection models [Lister, 1972; Anderson et al., 1977] have suggested values similar to those for good oil-producing sandstones, 1-1000 millidarcies $\left(10^{-11}-10^{-8} \mathrm{~cm}^{2}\right)$. Values for altered to fresh, unfractured basalt, ranging from 0.001 to 1 microdarcies $\left(10^{-14}-10^{-17} \mathrm{~cm}^{2}\right)$ were measured in the laboratory [Johnson, 1980 ]. This range of some ten orders of magnitude for the prediction of permeability of the ocean crust, though a large discrepancy, is tempered by the realization that laboratory permeability and crack-counting measurements are almost certainly not representative of oceanic crustal permeability.

Because an understanding of oceanic crustal permeability is so crucial to understanding convection beneath the sea floor, we made in situ measurements of permeability in layer $2 \mathrm{~A}$ of the oceanic crust by conducting flow tests across packed intervals at DSDP site 504B from the D/V Glomar Challenger (leg 69) (Figure 1a). The high heat flow flank of the Costa Rica Rift was chosen because of the apparent rapid sealing of convection and expected good drilling conditions close to the ridge axis (Figure $1 b$ ).

\section{THE EXPERIMENTS}

Three types of hydrogeologic experiments were conducted at site 504B. In order to determine in situ permeability and pore pressure, a packer was inflated downhole isolating varying segments of the bottom of the wellbore. In one type of test a pressure pulse or 'slug' was pumped into the formation using surface pumps. The decay character of this pressure pulse was measured and permeability determined. The method is described in detail below. Since geologic media are not uniformly permeable, a 'bulk' permeability over the tested interval is computed. Experiments conducted over a number of different intervals yield the variation in permeability in different lithologic units. Because the forma- tion turned out to be rather permeable, a constant rate injection test was also conducted. In this case the surface pumps maintain a constant flow rate downhole for several tens of minutes and the formation pressure is monitored. This is another test which yields a determination of bulk permeability.

Formation pore pressure was estimated in two different ways. In reasonably permeable sections we compared the pressure within the packed-off interval before and after flow tests were conducted. In the less permeable sections we analyzed the slug tests, because as the pressure pulses decay, they asymptotically approach in situ pore pressure.

The final type of experiment we performed was designed to study in situ fractures and voids. An ultrasonic borehole televiewer (described by Zemanek et al. [1970]) was deployed downhole to give an 'acoustic' picture of the natural fracture distribution of the upper oceanic crust and to help us interpret our permeability results in terms of lithostratigraphic variations. The results of the televiewer survey are summarized below and are described in detail by Zoback and Anderson [1982].

A Lynes International During-Drilling-Safety-Test tool (DDST) was included in the bottom hole assembly during reentry of DSDP hole 504B after drilling was completed. The DDST tool consists of a 1-m-long rubber, inflatable packer mounted $3 \mathrm{~m}$ above the drill bit. Two kinds of go-devils were used (illustrated in Figure 2, $b$ and $c$ ). For the permeability and pore pressure tests a 'safety' go-devil diverts fluid flow into the packer until inflation produces a firm seal against the wellbore. A shear plug is then blown, which opens the packed formation to direct pumping from the surface (Figure $2, b)$. Since flow 'through the annulus (the space between the wellbore and the outside of the drill pipe) is prevented by the inflated packer, the fluid must flow directly into the formation below the packer. The packer remains locked in the inflation mode until a steel ball is dropped to deflate the tool. A downhole pressure recorder is mounted at the front tip of the go-devil, giving direct in situ pressure measurements in the packed-off formation. In the other type of test a 'sampler' go-devil is used and a 60-liter sample of pore fluid is automatically taken after the packer inflates (Figure 2, c). In this case the sample chamber and the wellbore beneath the packer are in communication and the pressure recorder again gives in situ formation pressure during the sampling operation.

\section{The Borehole Televiewer}

In order to map the natural fracture distribution of the wellbore and also to examine the lithostratigraphy of the entire hole (only $29 \%$ of the formations drilled were recovered during the coring operation), an ultrasonic borehole televiewer was deployed downhole 504B and also in hole 501 (which is located only $1 \mathrm{~km}$ west of 504B). The variations in lithologies encountered downhole are of importance to our understanding of the meaning of the permeability and pore pressure measurements described below. The general lithostratigraphy of hole 504B is shown in Figure 2, $a$. At site 504B the water depth was $3463 \mathrm{~m}$, and drilling during leg 69 penetrated $274.5 \mathrm{~m}$ of siliceous nannofossil ooze, siliceous limestone and chert, and $214 \mathrm{~m}$ of basaltic pillows and flows to a total depth of $395.2 \mathrm{~m}$ below sea level (see Figure 2, $a$ ). A series of dense chert layers were encountered $30 \mathrm{~m}$ above basement in both holes 501 and 504B. These layers were 


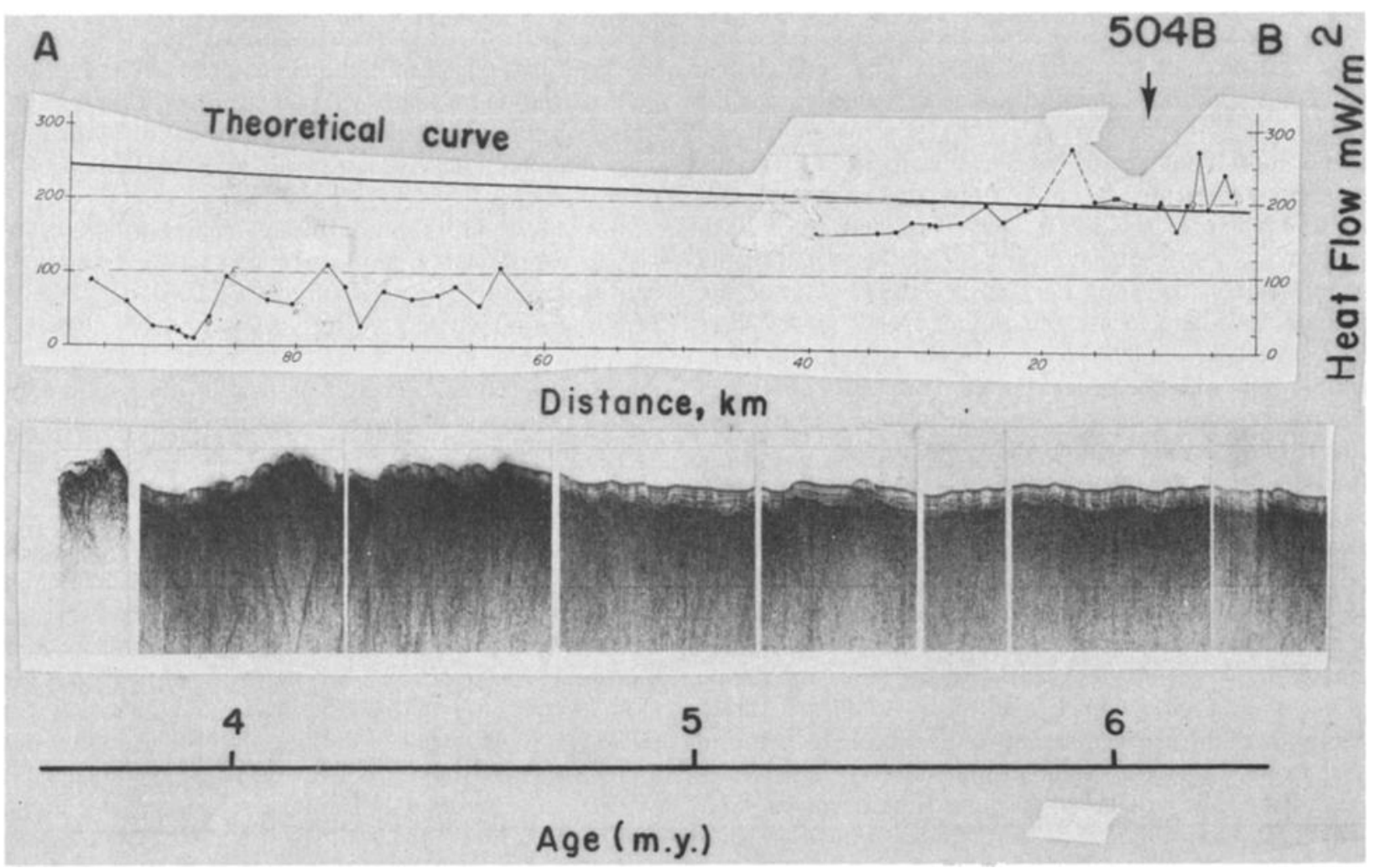

Fig. 1a. Heat flow (dots) versus age on the south flank of the Costa Rica Rift (see map, Figure 1b) shown over the seismic reflection profile, showing increase in sediment thickness with age on the ridge flank.

followed by thin chert lenses to the basement-sediment contact. A thick basaltic flow ranging in thickness from $7 \mathrm{~m}$ at hole 501 to $10 \mathrm{~m}$ at site $504 \mathrm{~B}$ was encountered below $10 \mathrm{~m}$ of large-diameter pillow basalts $(10-100 \mathrm{~cm})$. Below $50 \mathrm{~m}$ of alternating thin pillows and thick flow units, the basement grades into well-cemented, smectite-rich pillow units of small diameter $(\sim 10 \mathrm{~cm})$ at the bottom of hole $504 \mathrm{~B}$ [CRRUST, 1981].

\section{The Constant Rate Injection Test}

The packer was initially set at $\mathbf{3 7 8 0} \mathrm{m}$ in a flow unit $\mathbf{1 7 2 . 5}$ $\mathrm{m}$ above the bottom of the hole (Figure 2, $a$ ). Initial slug tests showed the formation to be too permeable for this measurement technique because the pulses decayed too rapidly to be analyzed (test 1, Figure 3), so a constant rate injection test was conducted. For 20 minutes the Challenger rig pumps flowed $100 \mathrm{gal} / \mathrm{min}$ of surface sea water downhole and into the formation. The pressure rose quickly to 13.2 bars above hydrostatic and remained within \pm 0.3 bars of that value for the final 18 minutes of the test, indicating that steady state conditions were achieved. Glover's formula [Snow, 1968] for constant rate injection tests gives formation permeability $k$ :

$$
k=\frac{c Q \ln [2 L / D]}{\pi 2 L H}
$$

where

$Q$ quantity of water pumped per unit time;

$L$ length of hole below the packer;

$D$ hole diameter;

$H$ net head acting on the formation;

$c=\mu / g \rho$ where $\mu$ is the fluid viscosity, $g$ is the acceleration due to gravity, and $\rho$ is fluid density. This term converts from hydraulic conductivity (with units of $\mathrm{cm} / \mathrm{s}$ ) to permeability (with units of $\mathrm{cm}^{2}$ or darcys) and is taken in our case to be $8.4 \times 10^{-10} \mathrm{~cm}^{2}$, assuming $20^{\circ} \mathrm{C}$ water.

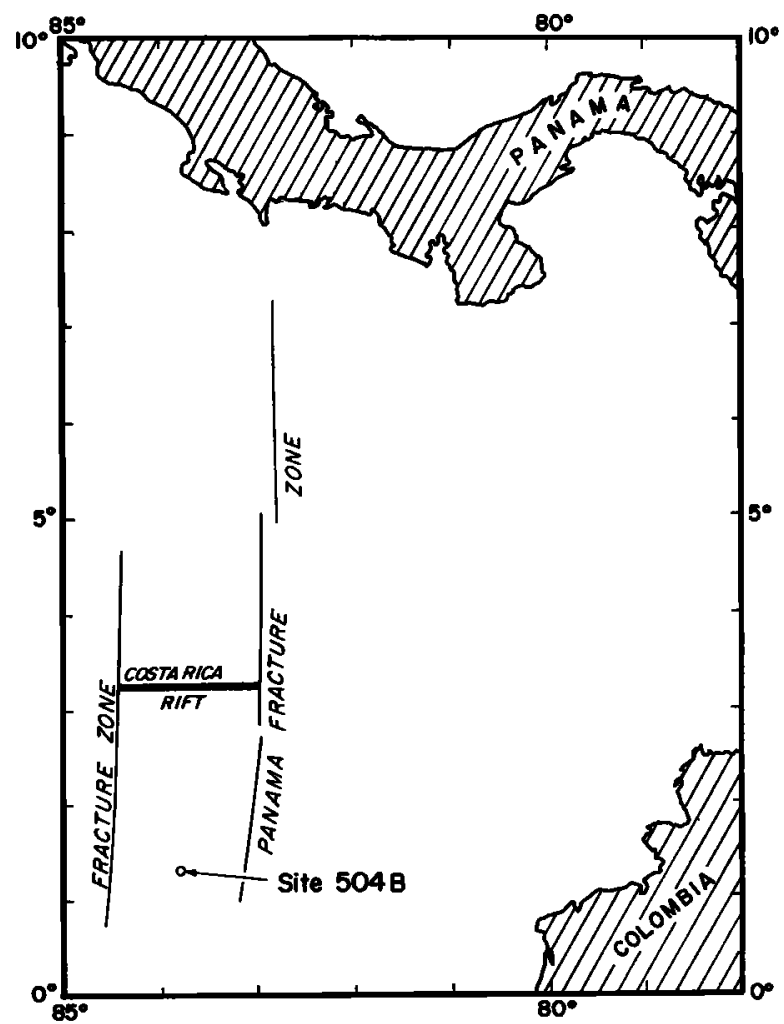

Fig. 1b. Map showing the Costa Rica Rift and the surrounding area. Location of DSDP site 504B is indicated. 


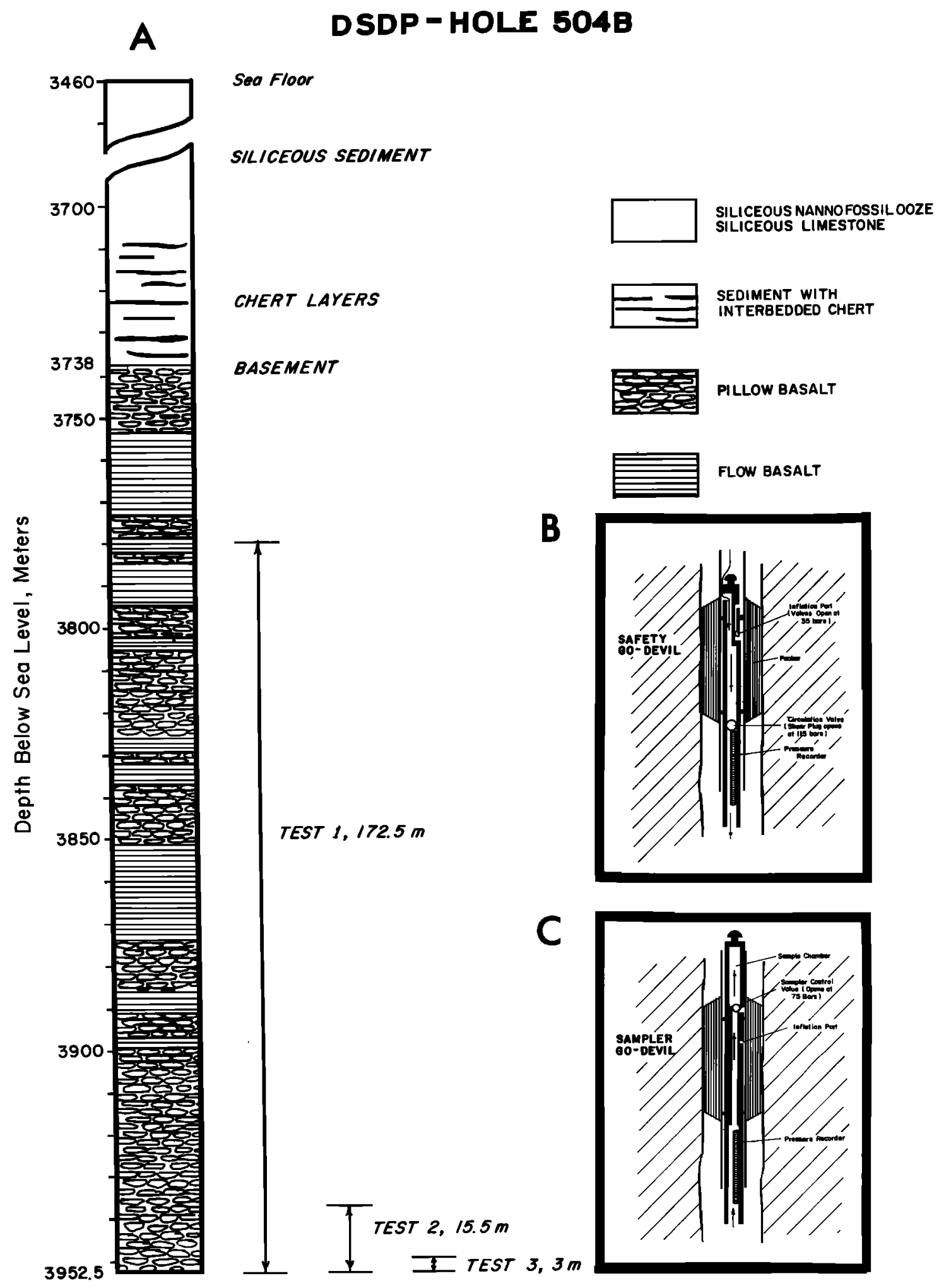

Fig. 2. (a) Lithostratigraphy from borehole televiewer records in DSDP hole 504B [Anderson and Zoback, 1981]. Test intervals of Figures 3 and 4 outlined. $(b)$ and $(c)$ Line drawings illustrating safety and sampler go-devil operations, respectively.

For test 1 (the $172.5-\mathrm{m}$ test interval), the bulk permeability computed from (2) is 37 millidarcys (md) or $3.7 \times 10^{-10} \mathrm{~cm}^{2}$. When successful, as in our case, this test gives a very accurate measure of the bulk permeability of the formation. We estimate the error to be $\pm 5 \%$, which is conservative for a test which held pressure with only $\pm 2 \%$ variation for 18 minutes.

\section{The Slug Tests}

Moving downhole, a slug test was conducted over the bottom $15.5 \mathrm{~m}$ of the hole. This was a fortuitous test which was made possible when the regulator valve on the sampler go-devil failed, instantly opening the 60-l evacuated chamber directly to the formation. Due to the sudden low pressure 

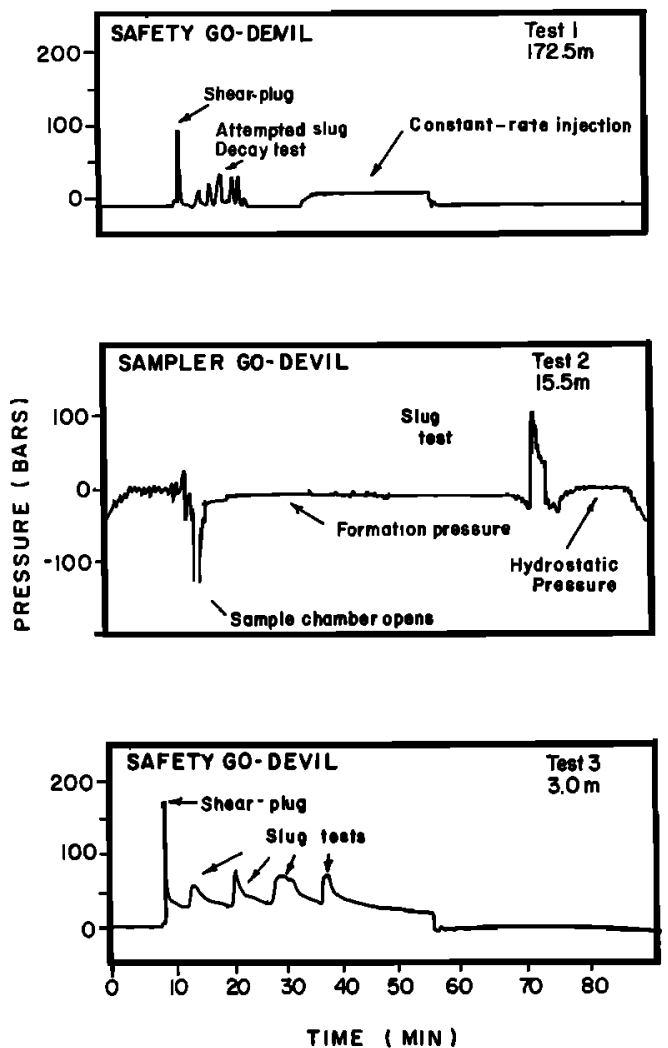

Fig. 3. In situ pressure versus time records for three hydraulic tests made below the packer at different depths in the well (see text).

beneath the rubber packer element, it was violently drawn down and over the drill collar, balling up against the wellbore between the packer and the drill bit. The formation was not only packed off $15.5 \mathrm{~m}$ off-bottom, but the drill string was stuck to a pull of 400,000 lbs. During the course of trying to free the drillstring, a slug test was conducted (test 2, Figure 3). This slug test resulted in a normalized pressure versus time plot from which permeability was computed in the following manner [after Bredehoeft and Papadapulos, 1980].

Consider a well system which is suddenly pressurized by injecting an additional amount of water above the static level with a high-pressure pump. The system is then shut in, and the excess pressure, $H$, following the initial pressure pulse, $\boldsymbol{H}_{0}$, is monitored. It is assumed that flow into the tested interval is primarily radial and that the hydraulic properties of the formation remain constant throughout the test. Another assumption is that volumetric changes due to the expansion and contraction of components of the system other than the fluid are negligible. The normalized pressure decay $(H /$ $H_{0}$ ) is shown by Cooper et al. [1967] and Bredehoeft and Papadopulos [1980] to be a function of two parameters, $\alpha$ and $\beta$, defined as

$$
\alpha=\frac{\pi r^{2} S}{V_{w} C_{w} \rho g_{w}} \quad \beta=\frac{\pi T t}{V_{w} C_{w} \rho_{w} g} \simeq \frac{T t}{r^{2}}
$$

where

$r \quad$ radius of the wellbore;

$S$ hydraulic storage coefficient of the tested interval;

$V_{w} \quad$ volume of system;

$C_{w} \quad$ compressibility of water;

$\rho_{w}$ density of water; g gravitational acceleration;

$t$ time

Cooper et al. and Bredehoeft and Papadopulos present a complex formulation for the pressure decay function that has been tabulated into a set of type curves in which the shapes of different decay curves for varying $\alpha$ are shown as a function of $H / H_{0}$ and $\beta$ (Figure $4, a$ ). Permeability $k$ is determined from the transmissivity $T$ by

$$
k=\frac{T c}{L}
$$

where $L$ is again the thickness of the interval isolated by the packer and $c$ is again introduced to convert from hydraulic conductivity to permeability, as in (2).

A semilogarithmic plot of $\boldsymbol{H} / \boldsymbol{H}_{0}$ versus time is superimposed on the type curves and translated along the $\beta$ axis into a position to best fit one of the curves [see Cooper et al., 1967]. The time $t^{*}$ is read off at the point where the slug test data overlie the $\beta=1$ point on the type curve for the appropriate $\alpha$. Then, from (3) and (4),
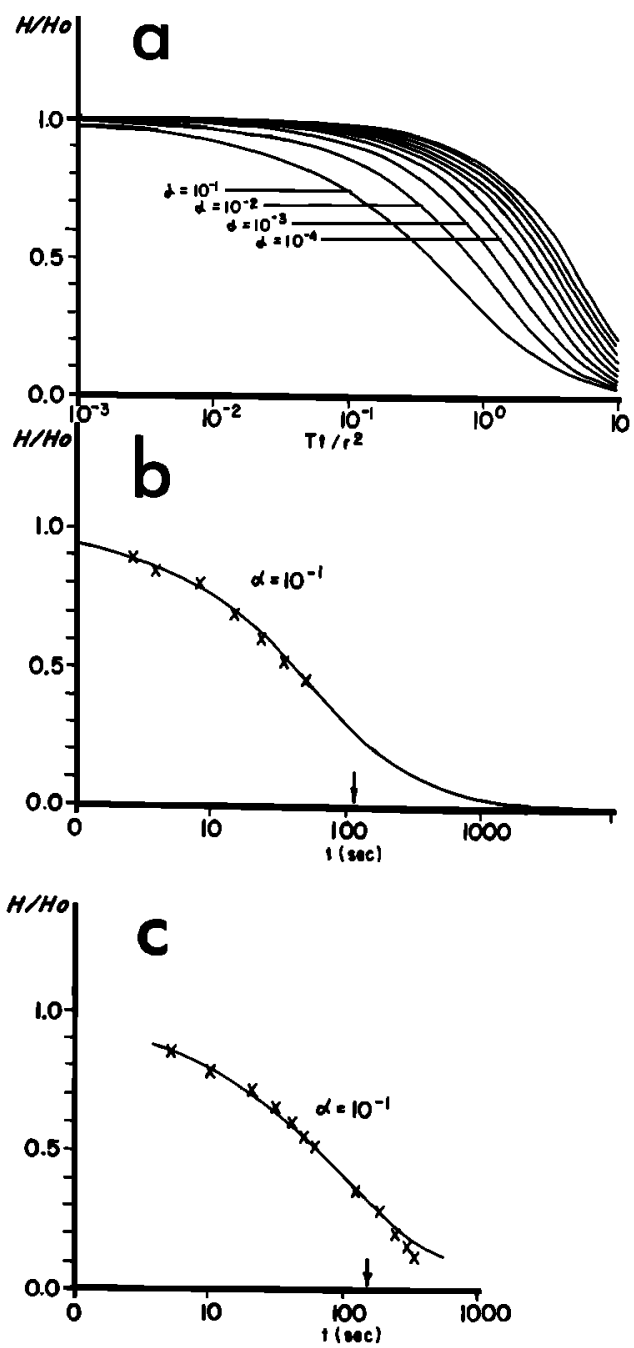

Fig. 4. (a) Slug test theoretical curves from Bredehoeft and Papadopolus [1980] and Cooper et al. [1967]. The decay in pressure $H$ versus the initial pulse $H_{0}$ is plotted versus $\beta$ for various $\alpha((3)$, text). (b) Slug tests over $15.5 \mathrm{~m}$ at bottom of hole. (c) Slug test over 3 m at bottom of hole. 


$$
k=\frac{V_{w} C_{w} \rho_{w} g}{L \pi t^{*}}
$$

The comparison of the shape of the $H / H_{0}$ versus time curve to the type curve also gives a test of the success of the experiment. Selection of the wrong type curve is a potential problem with the Cooper et al. method; however, such an error results in only a small corresponding error in the determination of $k$. It does result in a large error in determination of $S$, and the slug test is considered an inaccurate method for the determination of aquifer storage coefficient. The type curve fit is generally good enough to produce an order of magnitude fit, resulting in an error in the permeability of approximately $\pm 33 \%$. If a type curve cannot be fit to an order of magnitude, and the shape of the slug test curve differs significantly from that of the type curve, something went wrong with the experiment. Pressure-decay curves from experiments in which substantial leakage occurs around a damaged packer result in dramatically different curve shapes from those of the slug test [Matthews and Russell, 1967]. The data from test 2, Figures $3, b$ and $4, b$, and the $15.5 \mathrm{~m}$ slug test fit $\alpha=10^{-1}$ very satisfactorily, and from (5) yield a value of $k=4.5 \mathrm{md}\left(4.5 \times 10^{-11} \mathrm{~cm}^{-2}\right)$. For the test conducted over the lowermost $3 \mathrm{~m}$ of the hole (Figure 3, $c$ and Figure 4, c, pulse 1) the best-fitting type curve is also $\alpha=10^{-1}$ and $k=3.2 \times 10^{-11} \mathrm{~cm}$. We estimate from the goodness of fit of our data to the type curves that the error is well within the $\pm 33 \%$ for permeability results from the slug tests.

\section{Formation Pore Pressure}

A measure of the formation pore pressure was first obtained when the packer was stuck $15.5 \mathrm{~m}$ off the bottom of the hole during test 2 , because when using the sampler godevil, the downhole pressure gauge recorded the formation pressure and not the hydrostat. The pressure gauge monitored a constant pressure of $8 \pm 0.1$ bars below hydrostatic pressure for more than one hour after the chamber opened but before the hydraulic seal to the wellbore was broken, after which the hydrostatic head was again observed (Figure 3, test 2). In other words, the in situ pore pressure near the well was about $2 \%$ below the hydrostatic pressure of the water column ( $\sim 400$ bars $)$.

It is also possible to estimate the in situ pore pressure from the long-term pressure resulting from the decay of the slug tests (Figure 3, test 3). Cooper et al. [1967] have shown that for $\alpha=10^{-1}$ (which is appropriate to our tests, Figure 4) and $H / H_{0} \leq 0.5$, the decay of the pressure with time approximates that predicted by the line source of Ferris and Knowles [1954]. That is, $H / H_{0}$ is decaying in a manner inversely proportional to time and slowly approaching the in situ pore pressure. Because the line source approximation is applicable when $H / H_{0} \leq 0.5$, it is possible to use a standard extrapolation technique to determine the pore pressure [Matthews and Russell, 1967, pp. 18-19]. They show that

$$
\underline{H}=H^{*}-\frac{q \mu}{4 \pi k h} \ln \frac{t+\Delta t}{\Delta t}
$$

where $H^{*}$ is the in situ pore pressure, $\Delta t$ is the shut-in time, $t$ is the time during which flow into the interval occurred prior to the test, and $q$ is the average flow rate during $t$. By plotting $H$ as a function of $(t+\Delta t) / \Delta t$ on a logarithmic scale, we can determine $H^{*}$ by linearly extrapolating $H$ to $(t+\Delta t) / \Delta t=1$ (i.e. to $\Delta t \rightarrow \infty$ ).

For these experiments, $t$ is taken as $\mathbf{3 0}$ hours, the time between the completion of drilling, attachment of the packer assembly, and 'tripping' into the hole to conduct the test. The four slug tests with the packer set at $3 \mathrm{~m}$ above the bottom of the hole (test 3, figure 3,c), all extrapolate very clearly to negative pore pressures. The longest test shows an in situ pore pressure of about -12 bars (Figure 5). Note that from (6) the test results should not be linear on a semilogarithmic plot but should converge as $\Delta t$ passes the time at which $H / H_{0}=0.5$. Although the relatively large extrapolation shown by Figure 5 is imprecise, the results are reasonably consistent with the value of $\mathbf{- 8}$ bars indicated by test 2 .

\section{Discussion}

The data presented above indicate that (1) sections of layer $2 \mathrm{~A}$ of the oceanic crust on the flank of the Costa Rica Rift are under subhydrostatic pore pressure and (2) that the basalt is fairly permeable ( $\sim 37 \mathrm{md}$ in the pillow basalts of the lower $172.5 \mathrm{~m}$ of the hole, and $2-4 \mathrm{md}$ in the cemented pillows at the bottom of the hole). The downhole temperature logging results of Becker et al. [1982] also indicated that the hole penetrated an underpressured zone because depressed downhole temperatures (indicating downward flow of seawater into the formation) were measured in the lower part of the hole 54 days after the completion of drilling. They calculated that the rate of downward flow into the crust was about $30 \mathrm{gal} / \mathrm{min}$, and that most of the flow passed into the formation through a zone $50 \mathrm{~m}$ below the large basaltic sill in which we set our packer for the $172.5-\mathrm{m}$ slug test. From our measurement of the negative pore pressure responsible for this downflow, they calculated a permeability value of about $200 \mathrm{md}$, which is a factor of six higher than our constant rate injection test result of $37 \mathrm{md}$ over a considerably larger area.

These observations have important implications regarding hydrothermal processes near the Costa Rica Rift. The coexistence of underpressures and high permeability basalt suggests that cellular convection might be active in the oceanic crustal layer $2 \mathrm{~A}$, and that hole 504B penetrated into such a cell. However, the agreement between the average heat flow measured at the sea floor and that predicted by conductive lithospheric cooling models implies that any convection in the basement is sealed below the sea floor (Figure 1,b). Do our measurements then quantitatively support the existence of a capped convection system on the flank of the Costa Rica Rift?

Let us return to the Anderson-Skilbeck-Gartling model for convection in a basaltic layer sealed by a relatively impermeable sedimentary lid. The model requires that the hydraulic admittance of the sedimentary layer, $k_{s} / h$, be less than one tenth that of the basaltic layer $\left(a k_{b}\right)$ and that the Rayleigh number $R$ of the basaltic system be above the critical Rayleigh number $\boldsymbol{R}_{\boldsymbol{c}}$. If convection is occurring, the areal variability, though not well established, of the surface heat flow in the area $\left( \pm 25 \mathrm{mWm}^{-2}\right.$, about the mean of 200 $\mathrm{mWm}^{-2}$, as shown by Hobart et al. [1981]) suggests a cell dimension of about $5 \mathrm{~km}$. The wave number $a$ is then $6.3 \times$ $10^{-4} \mathrm{~m}^{-1}$.

D. Abbot (personal communication, 1981) has measured in situ and laboratory permeability of sediments similar to those at the surface near 504B of about $5 \mathrm{md}$ in the Guatemala Basin, a few degrees to the northwest of the 


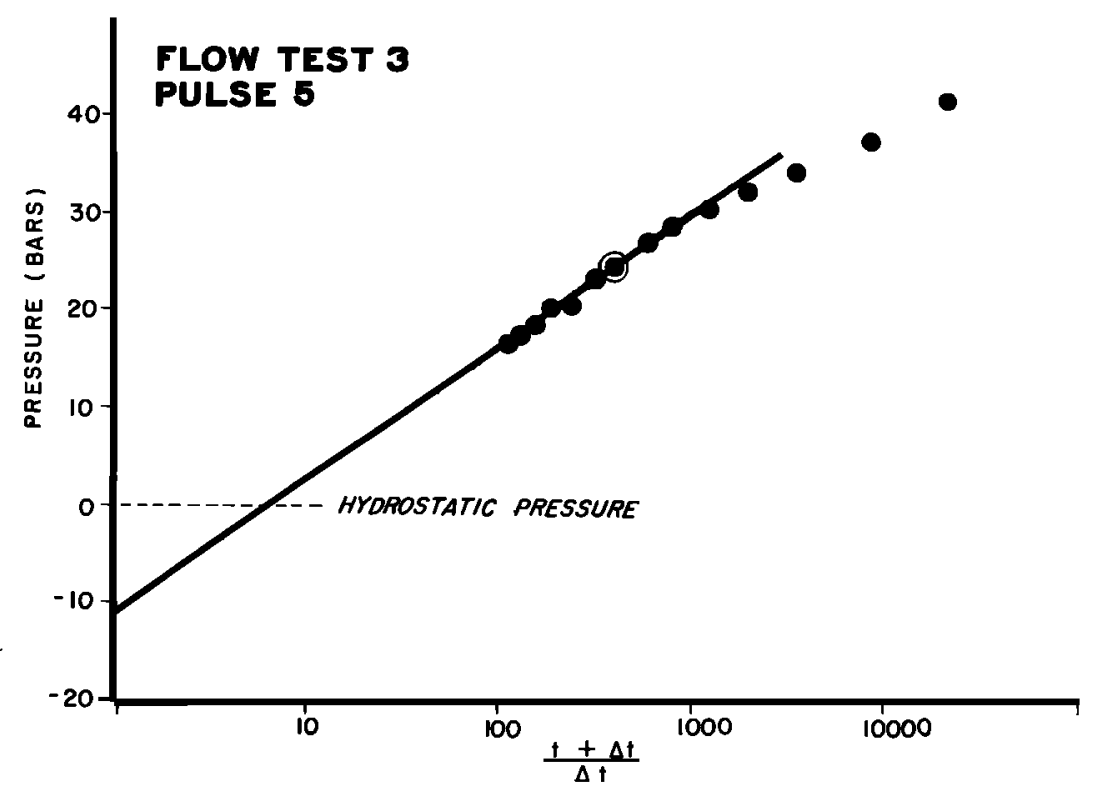

Fig. 5. Extrapolation of slug test pressure decay curve from last (and longest) pulse (Figure $3 c$ ) to in situ pore pressure. $H / H_{0}$ decays linearly after time at which $H / H_{0}=0.5$ (circled dot).

Costa Rica Rift. Bryant et al. [1975], however, suggest that a more reasonable permeability for the entire sedimentary section is in the range of $10^{-4}-0.1 \mathrm{md}$, and Crowe and Silva [1981] suggest values of up to 1 md for carboniferous sediment at $200 \mathrm{~m}$ depth. Thus an average estimate for the permeability of the sediment column would seem to be about $0.1 \mathrm{md}$. However, the existence of chert over the lower $30 \mathrm{~m}$ of the sediment column (with permeability that is several orders of magnitude lower than that of the sediment) suggests very much lower values, and it seems reasonable to guess 0.01 md as a maximum permeability for the sedimentary section. Taking $k_{s}=0.01 \mathrm{md}, h=280 \mathrm{~m}, a=6.3 \times 10^{-4}$ $\mathrm{m}^{-1}$, and $k_{b}=4-40 \mathrm{md}$, we have

$$
\frac{k_{s}}{a h k_{b}} \ll 0.1
$$

Then the condition prescribed by (1) would be satisfied, and the low hydraulic admittance of the sediments could apparently seal a convection system.

To know whether the oceanic crust is convecting below such a seal, the $R>R_{c}$ requirement must also be met. The Rayleigh number of a porous medium convecting in response to a vertical temperature difference $\Delta T$ across a layer of thickness $D$ is

$$
R=\frac{k \alpha g \Delta T D}{\kappa_{m} \nu_{m}}
$$

where $\alpha$ is the thermal expansion coefficient of the fluid, $\kappa_{m}$ is the effective thermal diffusivity of the medium, and $\nu_{m}$ is the viscosity of sea water.

Gartling and Anderson [1981] showed that the optimum vertical transport in a convecting two-layered porous medium with properties of the oceanic crust and overlying sediment occurs when the aspect ratio is nearly one. Given the theoretical heat flow for $6.1 \mathrm{~m}$.y.-old seafloor and the observed mean heat flow (which are both at $200 \mathrm{mWm}^{-2}$, Figure $1, b)$, the $\Delta T$ over a $3.0-\mathrm{km}$ thick convecting cell with $300 \mathrm{~m}$ of impermeable sediments and an aspect ratio near one would be $\sim 200^{\circ} \mathrm{C}$. The $R \simeq 24-240$ if the bulk permeability of the convecting medium is $\simeq 4-40$ md. Because of the large thermal expansion coefficient [Straus and Schubert, 1977] and temperature dependent viscosity of water [Kassoy and Zebib, 1975], $\boldsymbol{R}_{c}$ for the ocean crust is less than 10 regardless of whether the top of the cell is permeable or impermeable [Ribando et al., 1976]. Therefore convection in the basement is strongly indicated.

Further confirmation of convection in the layer 2 would be the negative pore pressure observed at the bottom of hole 504B, if we could show that such a pressure drop could reasonably be generated in a porous media convection cell. Gartling and Anderson [1982] have constructed plane layer finite element models to examine convection in the oceanic crust and sedimentary layers. Though not exactly modeling the Costa Rica Rift case, a model with $220 \mathrm{mWm}^{-2}$ of basal heat flow into a 3-km, two-layer porous medium with aspect ratio of one, $k_{b}=10^{-10} \mathrm{~cm}^{2}$, and $k_{s}=10^{-13} \mathrm{~cm}^{2}$ provides useful insight into the underpressure problem (Figure 6). A plot of presure in the cell (Figure $6, d$ ) shows that a model with $100 \mathrm{~m}$ of sediments predicts $\sim 3$ bar underpressures in the upper $500 \mathrm{~m}$ of the oceanic crust. The pressure field shown in Figure 6, $d$ is appropriate for comparison with our measurements because the values shown refer to the difference in pressure between the in situ and the expected hydrostatic pressure for a column of fluid at a temperture of $1.5^{\circ} \mathrm{C}$, which is essentially the condition introduced by the drill pipe and packer system.

The particular model shown in Figure 6 predicts lower bottom hole temperatures (actual bottom hole temperatures are about $120^{\circ} \mathrm{C}$ at $750 \mathrm{~m}$ subseafloor depth [Becker et al., 1982]) and larger amplitude variation in surface heat flow than are actually observed (observed heat flow variations are 175-225 $\mathrm{mWm}^{-2}$, Figure 1). A model with $300 \mathrm{~m}$ instead of $100 \mathrm{~m}$ of impermeable sediments would increase the temperatures within the cell while keeping the relative changes in temperature within the convection cell about the same. Thus the sediment-basement interface temperature would increase substantially, and the amplitude of surface heat 

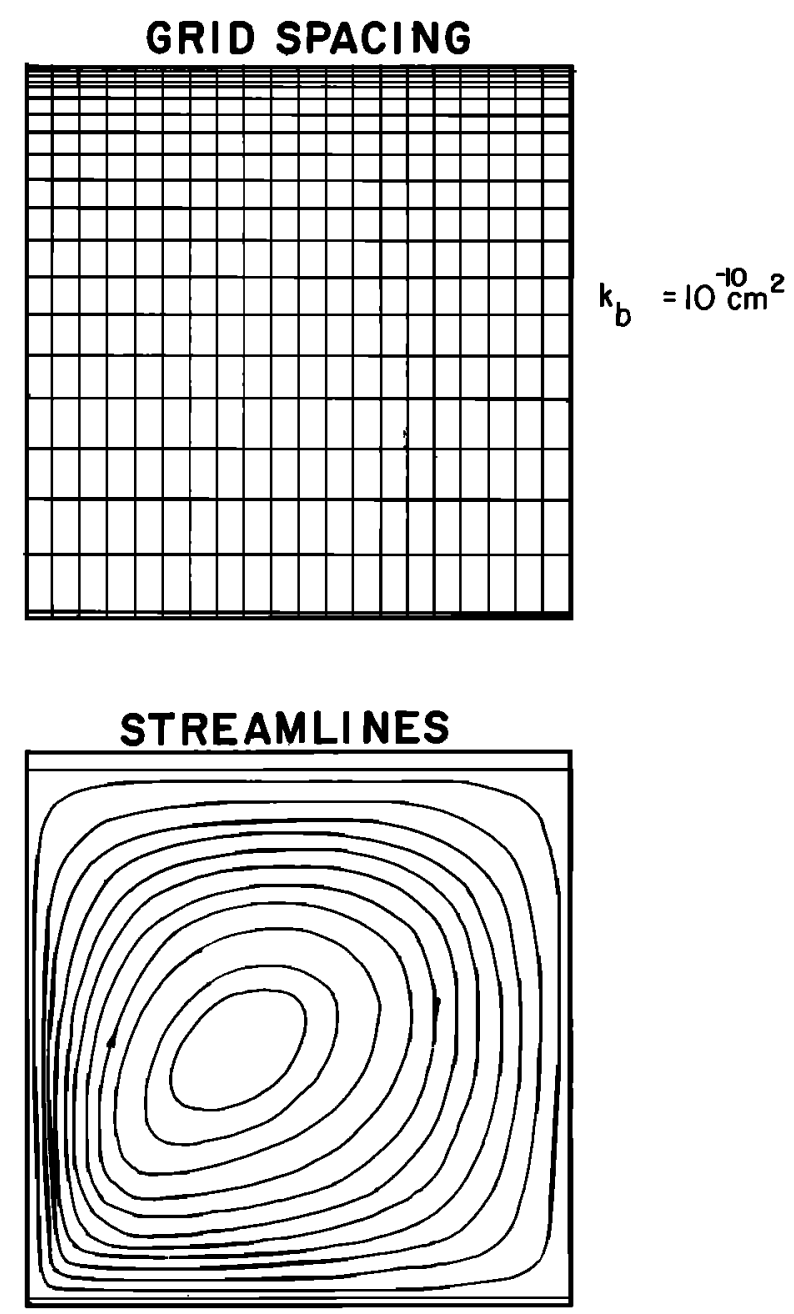

Fig. 6. A finite element model of hole 504B geometry from Gartling and Anderson [1980]. Sediment permeability is $0.01 \mathrm{md}$ and basalt permeability is $10 \mathrm{md}$. The lateral boundaries of the domain are assumed to be adiabatic and impermeable. The sediment surface is maintained at a constant temperature and pressure of $1.5^{\circ} \mathrm{C}$ and 600 bars, respectively. The lower boundary is impermeable with an imposed heat flux of $220 \mathrm{mWm}^{-2}$. Material properties include variable viscosity, thermal conductivity and thermal expansion coefficient. The fluid is Bousinesq. The pressure plot $(d)$ is presented as the in situ pressure minus the hydrostatic pressure appropriate to a column of fluid at $1.5^{\circ} \mathrm{C}$.

flow variation would correspondingly decrease. Also, the predicted bottom hole temperature for hole $504 \mathrm{~B}$ would increase into the appropriate range, and most importantly, the underpressures within the model would become even more negative. However, the Gartling and Anderson model assumes uniform rock permeability with depth, and the measurements described herein and the temperature measurements at 504B show that this is not quite the case locally. But a more complete knowledge of the permeability versus depth function is necessary before more sophisticated modeling is attempted. Thus, based upon the Gartling and Anderson modeling, the most logical explanation for observed underpressures in hole 504B is active convection in the ocean crust beneath the sediment on the flank of the Costa Rica Rift.
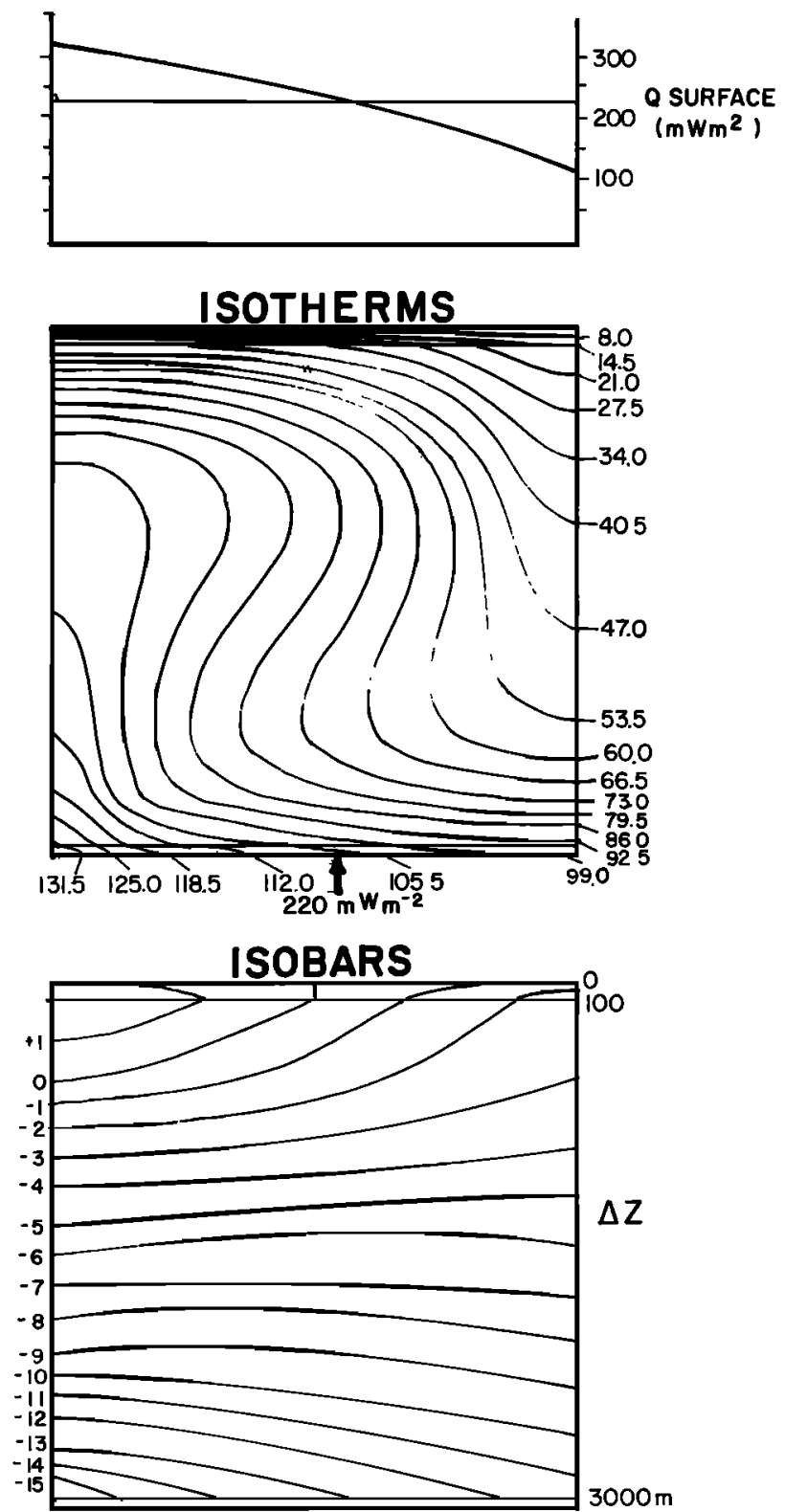

\section{Conclusions}

The relatively permeable nature of layer $2 A$, especially when compared to the overlying sedimentary lid with its basal chert layer, coupled with measurements of an underpressured zone beneath the sediment-basement contact, strongly indicates that DSDP hole 504B penetrated through a hydraulic lid into an active ocean crustal convection system several kilometers in extent. Just as the discovery of black smokers was direct substantiation of the geophysical predictions of active convection at ridge axes, we feel that high permeability and underpressures, when coupled with other scientific findings at DSDP leg 69 (particularly the thermal logs of Becker et al. [1982]) represent substantiation of hypothesized convection on the flanks of midocean ridges. It 
appears that hole 504B penetrated into a highly permeable zone within a crustal convection cell. The hydraulic seal isolating this system from the oceanic bottom water is apparently so effective that pore pressure $2 \%$ less than the hydrostat can be sustained only $200 \mathrm{~m}$ into the oceanic layer 2 A.

Much future work and many outstanding questions remain. What is the relative importance of the sediment layer, the chert layer, and the basaltic flows in affecting the hydraulic seal? How does permeability of these units vary with age on the flanks of midocean ridges? How does permeability vary with depth in layers 2 and 3 of the oceanic crust? On a smaller scale, how does the pore pressure vary across the proposed convection cell near 504B? Where does all the water drawn into the oceanic crustal acquifer at 504B go? Does it reappear at the sea floor somewhere nearby, or will it ever reappear? For how long will the system continue to draw water into the oceanic crust? Questions such as these will only be answered by further downhole experimentation at this and other sites on drilling ships such as the D/V Glomar Challenger.

Acknowledgments. We wish to thank the officers and crew of the D/V Glomar Challenger and particularly the Global Marine roughnecks for efforts expended on behalf of these experiments. $G$. Foss, the drilling superintendent, and J. Svitek of the U.S. Geological Survey were major contributors to the success of these experiments. The manuscript benefitted greatly from review by B. Raleigh, J. Bredehoeft, M. Hobart, and S. Hickman. This work was supported by National Science Foundation grant OCE-78-27026.

\section{REFERENCES}

Abbott, D., W. Menke, M. Hobart, and R. N. Anderson, Evidence of excess pore pressures in southwest Indian Ocean sediments, $J$. Geophys. Res., 86, 813-828, 1981.

Anderson, R. N., and M. A. Hobart, The relation between heat flow, sediment thickness, and age in the eastern Pacific, $J$. Geophys. Res., 77, 4472-4475, 1976.

Anderson, R. N., and J. N. Skilbeck, Oceanic heat flow, in The Sea, vol. 7, edited by C. Emiliani, Interscience, 1981.

Anderson, R. N., M. G. Langseth, and J. G. Sclater, The mechanisms of heat transfer through the floor of the Indian Ocean, $J$. Geophys. Res., 82, 3391-3409, 1977.

Anderson, R. N., M. A. Hobart, and M. G. Langseth, Geothermal convection through the oceanic crust and sediments in the Indian Ocean, Science, 204, 828-832, 1979.

Becker, K., M. G. Langseth, and R. P. Von Herzen, Deep crustal geothermal measurements at hole 504B, DSDP legs 69 and 70 , Init. Rep. Deep Sea Drilling Proj., in press, 1982.

Bredehoeft, J. D., and S. S. Papadopulos, A method for determining the hydraulic properties of tight formations, Water Resour. Res., $16,233-238,1980$.

Bryant, W. R., W. Hoffman, and P. T. Trabant, Permeability of unconsolidated and consolidated marine sediments, Gulf of Mexico, Mar. Geotechnol., 1, 1-13, 1975.

Clark, W. B., M. A. Beg, and H. Craig, Excess He in the sea: Evidence for terrestrial primordial helium, Earth Planet. Sci. Lett., 9, 45, 1970.

Cooper, H. H., J. D. Bredehoeft, and S. S. Papadopulos, Response of a finite-diameter well to an instantaneous charge of water, Water Resour. Res., 3, 263-269, 1967.

Corliss, J., et al., Submarine thermal springs on the Galapagos Rift, Science, 203, 1973, 1979.

Crowe, J., and A. Silva, Permeability measurement of equatorial Pacific carbonate ooze using direct measurement back-pressure techniques, submitted to J. Geophys. Res., 1981.
CRRUST, Drilling result from IPOD legs 69 and 70, site 504B on the Costa Rica Rift, Geol. Soc. Am. Bull., in press, 1981.

Davis, E. E., C. R. Lister, U. S. Wade, and R. D. Hyndman, Detailed heat flow measurements over the Juan de Fuca Ridge System, J. Geophys, Res., 81, 299-310, 1980.

Edmond, J., et al., Ridge crest hydrothermal activity and the balances of the major and minor elements in the ocean: The Galapagos data, Earth Planet. Sci. Lett., 46, 1-12, 1979.

Ferris, J. G., and D. B. Knowles, The slug test for estimating transmissibility, U.S. Geol. Surv. Groundwater Note 26, 1954.

Gartling, D. K., and R. N. Anderson, Finite element model of two layer porous media convection in the oceanic crust and overlying sediments, submitted to J. Geophys. Res., 1981.

Green, K. E., R. P. Von Herzen, and D. L. Williams, The Galapagos Spreading Center at $86^{\circ} \mathrm{W}$ : A detailed geothermal field study, J. Geophys. Res., 86, 979-986, 1981.

Hobart, M. A., M. G. Langseth, and R. N. Anderson, Geothermal survey of DSDP sites 501-505, Costa Rica Rift, Init. Rep. Deep Sea Drilling Proj., in press, 1982.

Johnson, D. M., Crack distribution in the upper oceanic crust, Init Rep. Deep Sea Drilling Proj., LI, LII, LIII, part 2, 1479-1490, 1980a.

Johnson, D. M., Fluid permeability of oceanic basalts, Init. Rep. Deep Sea Drilling Proj., LI, LII, LIII, Part 2, 1473-1477, 1980 .

Kassoy, D. R., and Z. Zebib, Variable viscosity effects on the onset of convection in porous media, Phys. Fluids, 18, 1649-1651, 1975.

Lister, C. R., On the thermal balance of ridges, Geophys. J. $R$. Astron. Soc., 26, 515-530, 19172.

Lupton, J. E., and H. Craig, Helium-3 and manganese at $21^{\circ} \mathrm{N}$ East Pacific Rise hydrothermal site, Earth Planet. Sci. Lett., 48, 261270, 1980.

Matthews, C. S., and D. G. Russell, Pressure build-up and flow tests in wells, Monogr. 1 , Soc. Pet. Eng. AIME, Dallas, Tex., 1967.

Ribando, R. J., K. E. Torrence, and D. L. Turcotte, Numerical models for hydrothermal circulation in the oceanic crust, $J$. Geophys. Res., 81, 3007-3012, 1976.

Salisbury, M. H., R. Stephen, N. I. Christensen, J. Francheteau, Y. Hamano, M. Hobart, and D. Johnson, The physical state of the upper levels of Cretaceous oceanic crust from the results of logging, laboratory studies, and the oblique seismic experiment at DSDP Sites 417 and 418, in Deep Drilling Results in the Atlantic Ocean: Ocean Crust, Maurice Ewing Ser., vol. 2, edited by M. Talwani, C. Harrison, and D. Hayes, pp. 113-134, AGU, Washington, D. C., 1979.

Sclater, J. G., J. Crowe, and R. N. Anderson, On the reliability of oceanic flow averages, J. Geophys. Res., 81, 2997-3006, 1976.

Snow, D. T., Rock fracture spacing, openings and porosities, J. Soil Mech. Found. Div. Am. Soc. Civ. Eng., 94, 73-91, 1968.

Speiss, F. N., et al., Geothermal system at $21^{\circ}$ N: East Pacific Rise, geophysical observations, Science, 207, 1421-1432, 1980.

Straus, J. M., and G. Schubert, Thermal convection in a porous medium: Effects of temperature and pressure dependent thermodynamics and transport properties, J. Geophys. Res., 82, 325334, 1977.

Williams, D. L., R. P. Von Herzen, J. G. Sclater, and R. N. Anderson, The Galapagos spreading center: Lithospheric cooling and hydrothermal circulation, Geophys. J. R. Astron. Soc., 38., 587, 1974.

Zemanek, J., R. C. Caldwell, E. E. Glenn, Jr., and L. J. Norton, Formation evaluation by inspection with the borehole televiewer, Geophysics, 35, 254-269, 1970.

Zoback, M., and R. N. Anderson, The implications of fracture distribution, structure, and stratigraphy from borehole televiewer imagery of the oceanic crust on the Costa Rica Rift, Nature, in press, 1981.
(Received July 23, 1981; revised November 19,1981 ; accepted November 25,1981 .) 